\title{
鼻出血に対する内視鏡下止血術の検討
}

\author{
富所 雄一1) ・ 中村光士郎1) ・菊池 孝2) ・河野 尚 ${ }^{31}$

\section{Clinical Investigation of the Posterior Epistaxis Treated with an Endoscope}

\author{
Yuichi Tomidokoro and Koshiro Nakamura \\ (Ehime Prefectural Central Hospital) \\ Takashi Kikuchi \\ (Ehime Prefectural Kitauwa Hospital) \\ Hisashi Kohno \\ (Kousei General Hospital)
}

\begin{abstract}
During the last nine and a half years (1991 2000) endoscopic electrocautery was performed on 18 patients (16 males and 2 females) with epistaxis at Ehime Prefectural Central Hospital. Using the endoscope all patients were investigated in the nasal cavity under general anesthesia. Six patients had bleeding sites at the posterior portion of the middle nasal meatus, seven patients in the olfactory cleft, three patients at the sphenoethmoidal recess, two patients in the inferior nasal meatus and one patient at the nasal septum. One patient had multiple bleeding sites. For these bleeding sites, electrocautery using the endoscope was successful. There were no complications after endoscopic electrocautery. Because of reduced invasion and greater safety, endoscopic electrocautery should be the first choice for patients who require complete surgical treatment of the posterior epistaxis.
\end{abstract}

Key words : posterior epistaxis, endoscopic electrocautery, surgical treatment

\section{はじめに}

鼻腔深部における出血でタンポンガーゼや後鼻孔バ

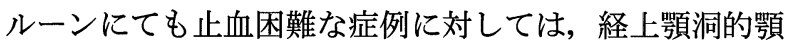
動脈結禁術, 外切開による穊骨動脈結紮術, あるいは動 脈塞栓術などの外科的治療が選択されてきた. しかし, 近年内視鏡の導入によって，侵襲がより少なく確実な止 血が可能となってきた. 今回われわれは最近の 9 年 6 力 月間に愛媛県立中央病院耳鼻咽喉科において入院を必要 とした鼻出血症例のうち, 内視鏡下電気凝固止血術を施 行した 18 例について, その有用性を検討したので若干の 文献的考察を加えて報告する.

\section{対象}

対象は 1991 年 4 月から 2000 年 9 月までの 9 年 6 力月 の間に入院を要した特発性鼻出血症例 74 例中, 内視鏡下 に電気凝固止血した症例 18 例（24.3\%）である. 内訳は 男性 16 例, 女性 2 例, 平均年齢はそれぞれ 58.8 歳, 59.5 歳であった. 高血圧症を合併していた症例は 6 例, 抗凝 固剤を内服していた症例は 1 例であった。

\section{当科における鼻出血患者の取り扱いについて}

図 1 に当科における鼻出血患者に対する治療方針を示 す．まず外来受診時にボスミンタンポンなどによる圧迫

1）愛媛県立中央病院耳鼻咽喉科

2) 愛媛県立北宇和病院耳鼻咽喉科

3）興生総合病院耳鼻咽喉科 


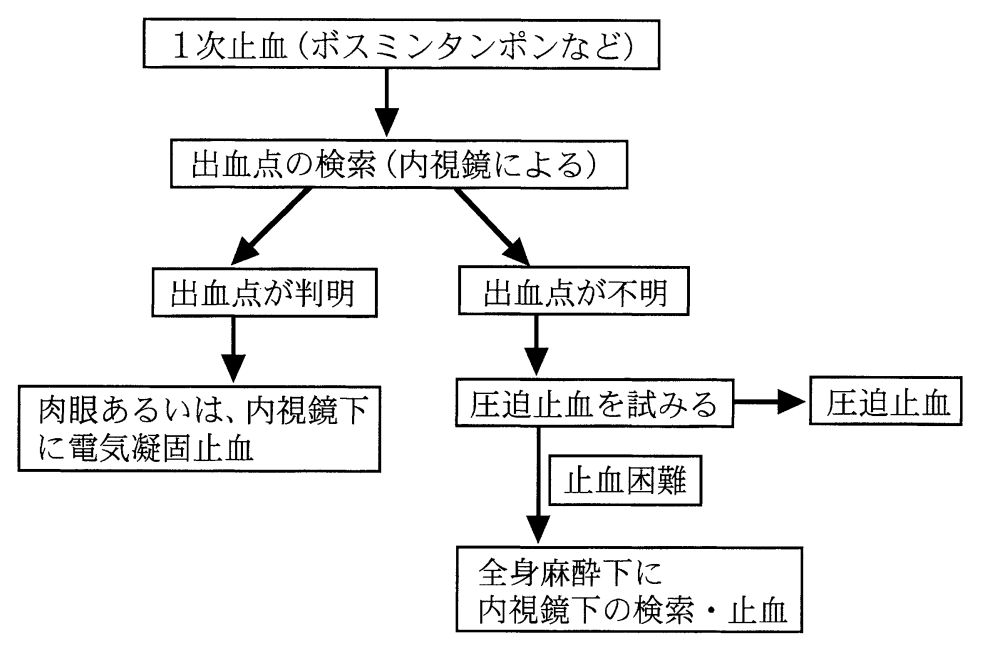

図 1 当科における鼻出血の治療方針

で1次止血を行い, 出血がおさまった時点でタンポンガー ゼを抜去し，全例ファイバースコープもしくは鼻用硬性 内視鏡にて出血点の検索を行う. 出血点が判明した場合 は，肉眼むしくは内視鏡下に電気凝固止血する。 また， 出血点不明の場合は，内視鏡所見をもとに疑わしい出血 部位を中心にタンポンガーゼで圧迫止血を試みるが，そ れでも止血困難な場合や，止血できても再出血の危険性 のある場合は, 入院の上経過を観察することとしている. 入院後も止血困難な症例に対しては全身麻酔下に内視鏡 にて出血点を検索することとしている.

\section{内視鏡下電気凝固止血術の方法}

内視鏡下に行う出血点の検索と止血術は, 術中出血に 対する気道確保と患者の鼻出血に対する不安を取り除く ために全例全身麻酔下に行った，鼻中隔弯曲症や肥厚性 鼻炎などがあり, 表面麻酔にても十分な視野を確保でき ない場合は鼻中隔矯正術や粘膜下下鼻甲介切除術を併用 した.

まずボスミンタンポンにて十分に粘膜を収縮させた後 に, $25^{\circ}$ (もしくは $70^{\circ}$ ) 前方斜視の鼻用硬性内視鏡にて 鼻粘膜を丹念に観察する．初診時に出血の認められた部 位，凝血塊の認められた部位を中心に推定される出血点 を検索する．特に蝶口蓋動脈の支配領域である中鼻道後 端, 下鼻道天蓋, 蝶穊陥凹部は十分に検索する．血管の 拡張，怒張などの所見が認められた場合，これを吸引管 の先端で触診し，出血の有無を確認する．血管の断端が 粘膜の小さな隆起として認められることも多く, 見過ご
さないように注意して観察する. 出血点は高周波電気凝 固装置を用いてボール電極で焼灼する，止血処置ができ ても他の部位からの出血もあり得ることを念頭に置い て，くまなく検索することが大切である，止血部位には キチン創傷保護剤をあてがい，軽くタンポナーデしてお く.タンポンガーゼは手術翌日に抜去し術後 1 週間は入 院の上経過を観察した。

\section{結果と症例の検討}

入院を要した鼻出血患者 74 症例の出血部位と止血方法 の関係を表 1 にまとめた，全身麻酔下に内視鏡下電気凝 固を施行したのは 18 例で全例出血部位を確認できた. そ の他の 56 例のうち出血点が判明した症例は 23 例で，圧 迫むしくは肉眼下の電気凝固にて止血可能であった. 残 りの 33 例は出血点が不明であったが圧迫にて止血し得 た. 中鼻道, 嗅裂部, 蝶穊陥凹部などの鼻腔深部からの 出血症例では内視鏡下に止血できた症例が大半を占めて いた. 内視鏡下止血術を行った症例では鼻中隔矯正術を 11 例に, 粘膜下下鼻甲介切除術を 2 例に施行した. 再出 血をきたした症例は 1 例あったが軽度であり，重篤な術 後合併症をきたした症例はなかった，以下に内視鏡下に 止血した代表例を提示する.

症例 $1: 70$ 歳, 男性.

家族歴：特記すべきことなし。

既往歴: 1992 年 7 月に他院にて鼻出血に対して入院加 療を受けたことがあるが, 保存的治療にて止血している.

現病歴: 2000 年 3 月 19 日早朝, 右鼻出血が出現した 
表 1 入院を要した鼻出血症例の出血部位と止血方法

\begin{tabular}{l|cccccccc}
\hline \hline & 下鼻道 & 中鼻道 & 嗅裂部 & 鼻中隔 & 蝶篩陥凹 & 不明 & 合計 \\
\hline 圧迫止血 & 2 & 2 & 5 & 3 & 0 & 33 & 45 例 \\
内視鏡下電気凝固 & $2 *$ & 6 & $7^{*}$ & 1 & 3 & 0 & 18 例 \\
肉眼下電気凝固 & 2 & 0 & 0 & 9 & 0 & 0 & 11 例
\end{tabular}

*は下鼻道と嗅裂部の 2 カ所に出血点が重複していた症例が含まれていることを示している.

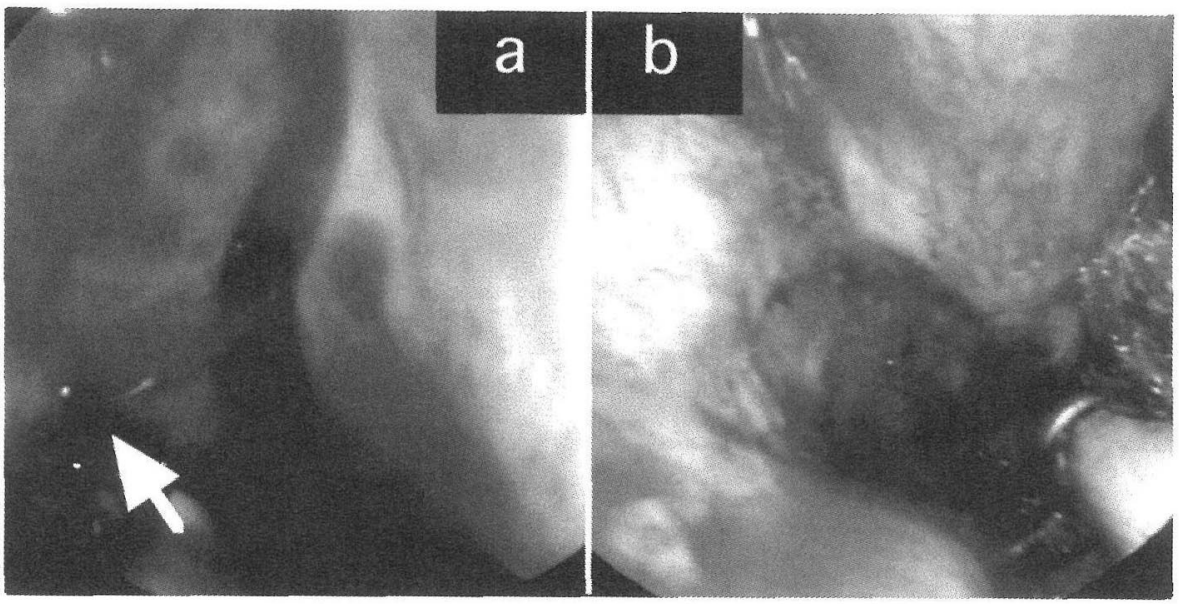

図 2 中鼻道後端よりの出血例（症例 1) $\mathrm{a}$ ：右中鼻道後端より噴射状に出血（矢印）が認められる。 $\mathrm{b}$ : 止血後の所見

ため近医救急外来を受診した。タンポンガーゼによる圧 迫止血処置を受け止血したが，同日精查加療目的にて当 院救急外来を受診した。

経過：初診時，処置中に再出血が生じ 1 次止血を行っ たが，再出血の危険性があったため即日入院とした。翌 日鼻腔内を観察すると，両側下鼻甲介後端付近に凝血塊 が認められたが出血点は不明であった。 3 月 21 日再度出 血したため，同日全身麻酔下に内視鏡にて鼻腔内を検索 したところ，右中鼻道後端より噴射状に出血が認められ 電気凝固止血した（図 2)。蝶口蓋動脈の分枝よりの出血 と考えられた。

症例 $2: 54$ 歳, 男性。

家族歴：特記すべきことなし。

既往歴：特記すべきことなし。

現病歴: 2000 年 6 月 18 日夜より右鼻出血が出現し, 近 医内科の救急外来を受診した。一時的に止血されたが䚻 宅後に再出血したため，翌日近医耳鼻咽喉科を受診した が,その処置中に血圧の低下を認めショック状態となり，
同日当科外来を紹介され受診した。

経過: 右嗅裂に凝血塊を認め, 同部位よりの出血を疑っ たが出血点の同定には至らず, 1 次止血後手術目的にて 入院となった。翌日全身麻酔下に内視鏡にて検索したと ころ, 嗅裂鼻中隔側に出血点と思われる部位が認められ 電気凝固止血した（図 3)。前篩骨動脈の分枝よりの出血 と考光られた。

症例 $3: 52$ 歳, 男性.

家族歴：特記すべきことなし。

既往歴 : 高血圧.

現病歴: 2000 年 6 月 15 日右鼻出血が出現したため, 近 医にてタンポンガーゼによる圧迫止血処置を受けた。6 月 18 日,再度右鼻出血吕出現したため同日当院救急外来 を受診した。

経過：右下鼻道後端に凝血塊を認めたが出血点は不明

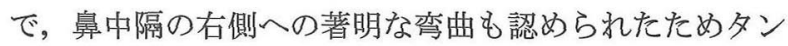
ポンガーゼの挿入は困難であった。入院の上，右鼻内に 後鼻孔用バルーンを留置して止血を試みたが，その後も 


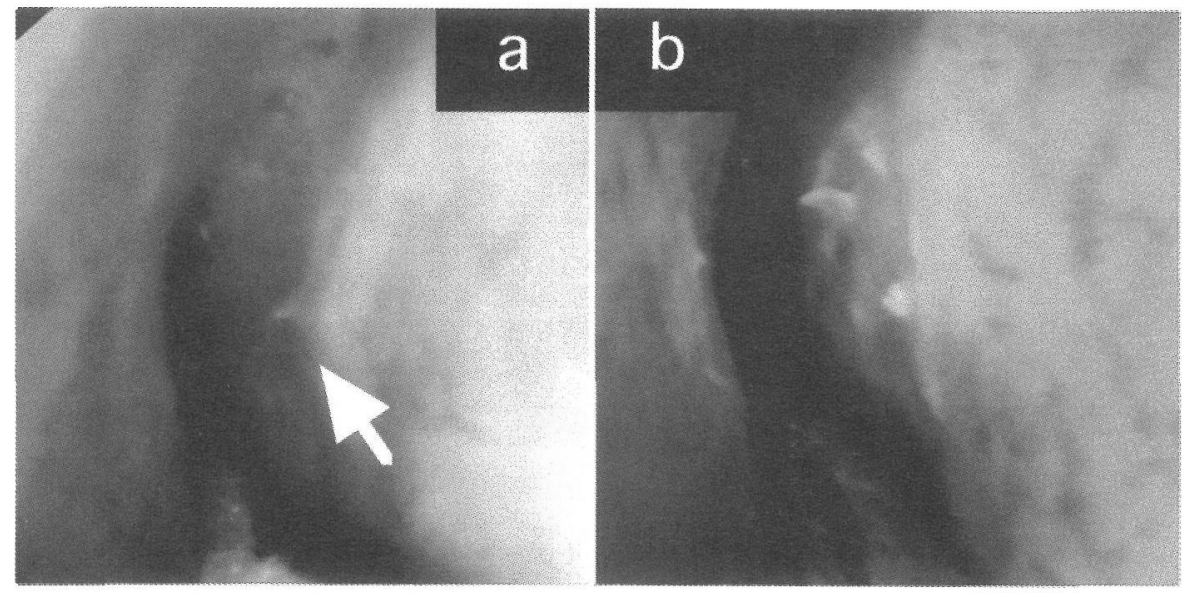

図 3 嗅裂部よりの出血例（症例 2） $\mathrm{a}$ ：右嗅裂部に瘤状の粘膜の突出（矢印）が認められる。 $b$ ：止血後の所見

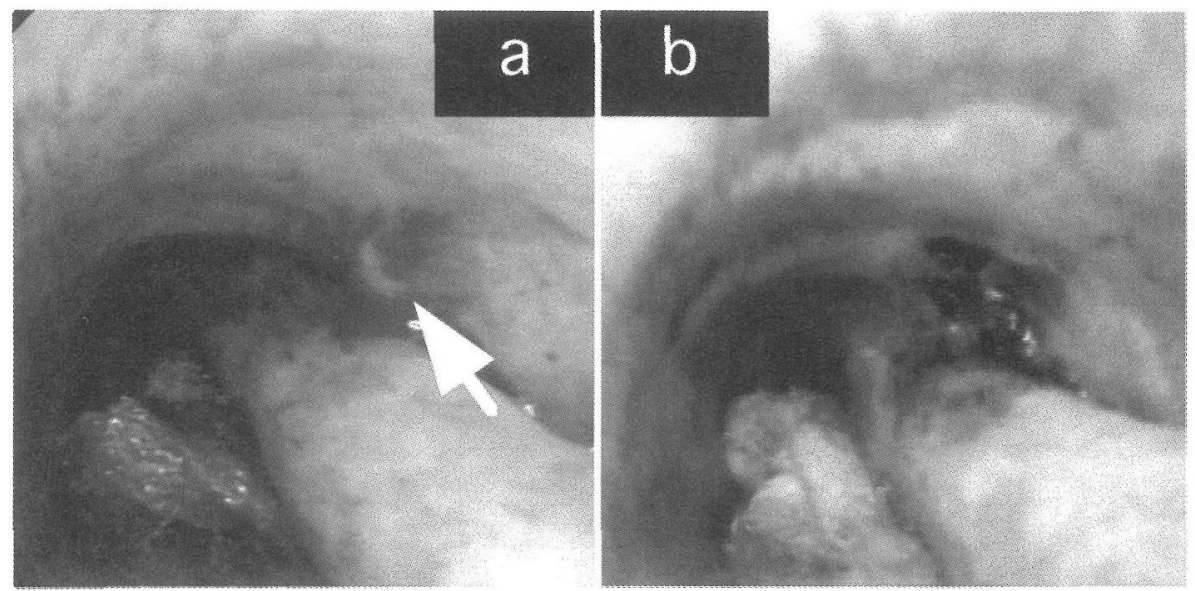

図 4 下鼻道天蓋内側よりの出血例（症例 3） $\mathrm{a}$ ：右下鼻道天蓋に粘膜の突出（矢印）およびその部位からの出血が認められる。 b : 止血後の所見

出血持続するため翌日全身麻酔下に内視鏡にて出血点を 検索した。鼻腔内を上部より順次検索しても出血点が認 められず，最後に下鼻道を点検したところ天蓋内側に出 血点を認め電気凝固止血した（図 4)。蝶口盍動脈の分枝 よりの出血と考えられた。本症例は出血点の検索に難渋 したが，このような症例こそ内視鏡下電気凝固止血術の 良い適応であると思われた。

$$
\text { 考察 }
$$

鼻出血の止血方法には保存的治療亡外科的治療があ
る。保存的治療にはタンポンガーゼによる圧迫, 後鼻孔 用バルーンの留置などがあるが, 鼻腔深部の出血の場合, 出血点を的確に圧迫することが困難なため治療に難渋す ることが多い。保存的治療が無効な症例に対して外科的 治療が施されるが，実際の臨床ではいつ保存的治療から 外科的治療へ切り替えるべきか判断に迷らことが多い。 この判断基準について具体的に検討している報告は少な いが，Shaw ら 1) は入院を要した鼻出血患者 65 症例を検 討し，保存的治療で止血できた 51 例は，入院 3 日目以降 には出血がなかったとし，72 時間保存的治療にて止血困 
難な症例に対しては外科的治療を考慮すべきであると報 告している. また，Kotecha ら 2) は入院を要した難治性 鼻出血患者で保存的治療をした 663 症例のうち, 24 時間 以内に止血できた症例は 108 例（16.3\%)，24〜 48 時間 以内に止血できた症例が 460 例 (69.4\%)，48 時間以内 に止血できなかった症例は 95 例 (14.3\%) であったと報 告している. このことは, 保存的治療で 48 時間以上止血 できない症例には外科的治療を考慮した方がよいという ことを示唆している. ただし, 出血量が多く早急な止血 が必要な場合には外科的治療への移行を躊躇すべきでは ない．また，外来診療で圧迫にて一時的に止血するが帰 宅後に再出血する症例や, 来院時には止血しているが頻 回に出血を繰り返す反復性鼻出血に対しても, 効果を確 認できないまま外来で保存的治療を続けるのではなく, 外科的治療を考慮することが肝要である. 今回の検討で も, 入院後手術までの時間は平均 37 時間であり, 前述の 報告とあわせて考えると, 入院後保存的治療で 2 日以内 に止血できない場合は何らかの外科的治療が必要である と考えるのが妥当であろう.

外科的治療としては, 従来, 経上顎洞的領動脈結禁術, 外切開による篩骨動脈結禁術, あるいは動脈塞栓術など の方法が選択されてきたが，これらの方法は侵襲が大き く, また種々の合併症が報告されている314). 一方, 近年, 内視鏡を導入することにより低侵襲，かつ安全な外科的 治療が可能となってきた. Elwany $~^{5)}$ ( 鼻腔深部の特発 性鼻出血38症例に対して内視鏡下に電気凝固止血術を施 行し, 30 例を止血し, 術後の合併症は口蓋のしびれを訴 えた 3 例のみであったと報告している.ささらに，この止 血方法の低侵襲性, 安全性, 有効性, そして術後創部処 置の簡単なことについても言及している，一方 Pollice ら ${ }^{6)}$ は入院が必要であった鼻出血 249 症例（外傷等も含 む) について検討しているが，そのうち 30 例に内視鏡下 の電気凝固止血術を施行し, 全例止血に成功しており, この方法が鼻出血患者に対してきわめて有用であると評 価している. 今回われわれの検討した内視鏡下電気凝固 止血術施行例 18 例については, 全例止血に成功し術後合 併症も認めなかった，鼻出血の治療は患者の状態，診察 医の技量, 病院の設備によってさまざまであるが, 難治 性鼻出血の止血術として内視鏡下電気凝固術は侵襲が小 さく，また術後の合併症もほとんどないため外科的治療 の第 1 選択になりらると考える.

また，内視鏡を使用した他の止血方法として，内視鏡
下蝶口蓋動脈結紫術7) や内視鏡下蝶口蓋動脈電気凝固 術8) が報告されている．黄川田ら ${ }^{8)}$ は蝶口蓋動脈からの 出血が疑われるものの出血点が明らかでない場合，ある いは再発がみられる場合には内視鏡下に蝶口蓋孔におい て蝶口蓋動脈を露出させ，これを凝固遮断する方法が最 も確実であると報告している．今後適応があれば試みる べき方法であると思われる。

\section{まとめ}

1. 入院を要した鼻出血症例のうち内視鏡下電気凝固止 血術を施行した 18 例について検討した。

2. 鼻腔深部の難治性出血に対して内視鏡下電気凝固止 血術は有用であり，侵襲が小さく，合併症がほとんどな いために外科的治療の第1選択になりらると考えられた。

本論文の要旨は第26回日本耳鼻咽喉科学会中国四国地方部会 連合学会（平成 12 年 12 月, 岡山市）において口演した.

\section{参考文献}

1) Shaw $\mathrm{CB}$, Wax MK and Wetmore SJ : Epistaxis; a comparison of treatment. Otolaryngol Head Neck Surg 109:60 65, 1993.

2) Kotecha B, Fowler S, Harkness $P$, et al. : Management of epistaxis; a national survey. Ann R Coll Surg Engl 78 : 444 446, 1996.

3) Cullen MM and Tami TA : Comparison of internal maxillary artery ligation versus embolization for refractory posterior epistaxis. Otolaryngol Head Neck Surg 118:636 642, 1998.

4）夜陣紘治, 立川隆治：鼻出血の手術的治療. JOHNS 16 : $1629 \sim 1633,2000$.

5) Elwany $\mathrm{S}$ and Abdel-Fatah $\mathrm{H}$ : Endoscopic control of posterior epistaxis. J Laryngol Otol $110: 432 \sim 434,1996$.

6) Pollice PA and Yoder MG : Epistaxis: a retrospective review of hospitalized patients. Otolaryngol Head Neck Surg $117: 49 \sim$ 53, 1997.

7) Voegels RL, Thome DC, Iturralde PP, et al. : Endoscopic ligature of the sphenopalatine artery for severe posterior epistaxis. Otolaryngol Head Neck Surg 124:464 467, 2001.

8）黄川田徹：鼻出血止血術. 耳鼻咽喉科診療プラクティス, 1. 鼻科手術支援機器の Up to Date (池田勝久編). $60 \sim 63$ 頁, 文光堂, 東京, 2000 .

原稿受付 : 平成13年11月 2 日 原稿採択 : 平成14年 1 月 16 日 別刷請求先 : 富所雄一 干790-0024 松山市春日町83 愛媛県立中央病院耳鼻咽喉科 